\title{
Cometabolism of $\mathrm{Cr}(\mathrm{VI})$ by Shewanella oneidensis MR-1 Produces Cell-Associated Reduced Chromium and Inhibits Growth
}

\author{
Sarah S. Middleton, ${ }^{1}$ Rizlan Bencheikh Latmani, ${ }^{2}$ Mason R. Mackey, ${ }^{3}$ \\ Mark H. Ellisman, ${ }^{3}$ Bradley M. Tebo, ${ }^{2}$ Craig S. Criddle ${ }^{1}$ \\ ${ }^{1}$ Department of Civil and Environmental Engineering, Stanford University, \\ Stanford, California 943051; telephone: (650) 723-9032; fax: (650) 725-3164; \\ e-mail: criddle@stanford.edu. \\ ${ }^{2}$ Marine Biology Research Division and Center for Marine Biotechnology \\ and Biomedicine, Scripps Institution of Oceanography, University of \\ California-San Diego, La Jolla, California 92093-02022 \\ ${ }^{3}$ National Center for Microscopy and Imaging Research, University of \\ California-San Diego, La Jolla, California 920933
}

Received 4 November 2002; accepted 1 April 2003

Published online 23 June 2003 in Wiley InterScience (www.interscience.wiley.com). DOI: 10.1002/bit.10725

\begin{abstract}
Microbial reduction is a promising strategy for chromium remediation, but the effects of competing electron acceptors are still poorly understood. We investigated chromate $(\mathrm{Cr}(\mathrm{VI}))$ reduction in batch cultures of Shewanella oneidensis MR-1 under aerobic and denitrifying conditions and in the absence of an additional electron acceptor. Growth and $\mathrm{Cr}(\mathrm{VI})$ removal patterns suggested a cometabolic reduction; in the absence of nitrate or oxygen, MR-1 reduced $\mathrm{Cr}(\mathrm{VI})$, but without any increase in viable cell counts and rates gradually decreased when cells were respiked. Only a small fraction $(1.6 \%)$ of the electrons from lactate were transferred to $\mathrm{Cr}(\mathrm{VI})$. The 48-h transformation capacity (Tc) was $0.78 \mathrm{mg}$ (15 $\mu$ moles) $\mathrm{Cr}(\mathrm{VI})$ reduced $\cdot[\mathrm{mg} \text { protein }]^{-1}$ for high levels of $\mathrm{Cr}(\mathrm{VI})$ added as a single spike. For low levels of $\mathrm{Cr}(\mathrm{VI})$ added sequentially, Tc increased to $3.33 \mathrm{mg}$ (64 $\mu$ moles) $\mathrm{Cr}(\mathrm{VI})$ reduced $\cdot[\mathrm{mg} \text { protein }]^{-1}$, indicating that it is limited by toxicity at higher concentrations. During denitrification and aerobic growth, MR-1 reduced $\mathrm{Cr}(\mathrm{VI})$, with much faster rates under denitrifying conditions. $\mathrm{Cr}(\mathrm{VI})$ had no effect on nitrate reduction at $6 \mu \mathrm{M}$, was strongly inhibitory at $45 \mu \mathrm{M}$, and stopped nitrate reduction above $200 \mu \mathrm{M}$. Cr(VI) had no effect on aerobic growth at $60 \mu \mathrm{M}$, but severely inhibited growth above $150 \mu \mathrm{M}$. A factor that likely plays a role in $\mathrm{Cr}(\mathrm{VI})$ toxicity is intracellular reduced chromium. Transmission electron microscopy (TEM) and electron energy loss spectroscopy (EELS) of
\end{abstract}

Correspondence to: Craig S. Criddle

Contract grant sponsor: the National Institute of Environmental Health Sciences (NIEHS) Superfund Basic Research Program

Contract grant numbers: ES04911 (to the Institute for Environmental Toxicology at Michigan State University), ES10337 to the University of California San Diego)

Contract grant sponsor: the National Science Foundation Graduate Fellowship Program (to SM)

Contract grant sponsor: the Swiss National Science Foundation Post Graduate Fellowship (to RBL). denitrifying cells exposed to $\mathrm{Cr}(\mathrm{VI})$ showed reduced chromium precipitates both extracellularly on the cell surface and, for the first time, as electron-dense round globules inside cells. (c) 2003 Wiley Periodicals, Inc. Biotechnol Bioeng 83: 627-637, 2003.

Keywords: Shewanella oneidensis MR-1; chromate; reduction; denitrification; inhibition

\section{INTRODUCTION}

Hexavalent chromium [Cr(VI)] is an Environmental Protection Agency (EPA) priority pollutant and a known carcinogen. Due to its widespread industrial use, it is often found in contaminated groundwater. In order to achieve levels of chromium below the EPA maximum contaminant level (100 $\mu \mathrm{g} / \mathrm{L})$, remediation strategies focus on the reduction of $\mathrm{Cr}(\mathrm{VI})$ to insoluble trivalent forms, which are relatively stable and nontoxic. The only compounds able to oxidize trivalent chromium at any appreciable rate are manganese oxides (Eary and Rai, 1987). Bioremediation may be effective for the removal of $\mathrm{Cr}(\mathrm{VI})$ from groundwater, as many aerobic and anaerobic microorganisms reduce $\mathrm{Cr}(\mathrm{VI})$ to $\mathrm{Cr}$ (III) while utilizing a wide range of electron donors (Bopp and Ehrlich, 1988; Ishibashi et al., 1990; Shen and Wang, 1993; Rege et al., 1997; Tebo and Obraztsova, 1998; Francis et al., 2000; Myers et al., 2000). However, there are few studies that compare the kinetics of $\mathrm{Cr}(\mathrm{VI})$ reduction by bacteria under different electron-accepting conditions or that study the effects of $\mathrm{Cr}(\mathrm{VI})$ on the reduction of other electron acceptors.

Shewanella oneidensis MR-1 (formerly Shewanella putrefaciens MR-1) is a facultative Gram-negative bacterium whose respiratory versatility has prompted interest in its use in bioremediation. A nonfermenting bacterium, MR-1 can 
reduce a variety of compounds, including iron (III), manganese (IV), nitrate, nitrite, thiosulfate, sulfite, trimethylamine N-oxide (TMAO), fumarate, uranium(VI), technetium(VII), Cr(VI), and elemental sulfur (Myers and Nealson, 1988, 1990; Lovley et al., 1989, 1991; Kostka and Nealson, 1995; Lloyd and Macaskie, 1996; Moser and Nealson, 1996; Krause and Nealson, 1997; Myers et al., 2000). Recently, the genome of MR-1 was sequenced by the Institute for Genomic Research, making MR-1 a prime candidate for physiological and gene expression studies of $\mathrm{Cr}(\mathrm{VI})$ reduction. In vitro studies by Myers et al. (2000) localized the chromate reductase activity of MR-1 cultures growing on fumarate to the cytoplasmic membrane. Viamajala et al. (2002a) recently reported Cr(VI) reduction during denitrification in MR-1 and showed that specific rates of $\mathrm{Cr}(\mathrm{VI})$ reduction changed with incubation time. They found that nitrate and nitrite inhibited specific rates of $\mathrm{Cr}(\mathrm{VI})$ reduction in stationary phase cells and that $\mathrm{Cr}(\mathrm{VI})$ inhibited nitrite reduction (Viamajala et al., 2002b). They did not examine the effect of $\mathrm{Cr}(\mathrm{VI})$ on nitrate reduction.

For bioremediation applications, it is important to know how various electron acceptors affect the rate of $\mathrm{Cr}(\mathrm{VI})$ reduction, as well as how $\mathrm{Cr}(\mathrm{VI})$ affects other terminal electron-accepting processes. In a mixed waste setting, bioremediation often hinges on understanding the sequence in which electron acceptors will be reduced. This work evaluates the kinetics and physiology of $\mathrm{Cr}(\mathrm{VI})$ reduction in $S$. oneidensis MR-1 under aerobic and denitrifying conditions and without additional electron acceptors. In addition, we study the effect of $\mathrm{Cr}(\mathrm{VI})$ on denitrification and aerobic growth. We show that the maximum specific rates and halfsaturation coefficients are highest for anaerobic conditions. We also show that in both cases $\mathrm{Cr}(\mathrm{VI})$ inhibits and, at high enough concentrations, halts growth. A possible mechanism of toxicity is suggested by the presence of intracellular globules containing reduced chromium, as revealed for the first time by EELS images.

\section{MATERIALS AND METHODS}

\section{Bacterial Cultures}

Shewanella oneidensis MR-1 was isolated from the anoxic sediments of Lake Oneida, NY (Myers and Nealson, 1988). MR-1 was obtained from Oakridge National Laboratory, stored as freezer stocks at $-80^{\circ} \mathrm{C}$ until use, when they were maintained aerobically on LB agar (g/L: tryptone, 10; yeast extract, 5; $\mathrm{NaCl}, 10$; agar, 12). All experiments were conducted in the medium of Myers and Nealson (1988) with the following composition: $9.0 \mathrm{mM}\left(\mathrm{NH}_{4}\right)_{2} \mathrm{SO}_{4}, 5.7 \mathrm{mM}$ $\mathrm{K}_{2} \mathrm{HPO}_{4}, 3.3 \mathrm{mM} \mathrm{KH} \mathrm{PO}_{4}, 2.0 \mathrm{mM} \mathrm{NaHCO} 3,1.01 \mathrm{mM}$ $\mathrm{MgSO}_{4}, 0.485 \mathrm{mM} \mathrm{CaCl}{ }_{2}, 67.2 \mu \mathrm{M} \mathrm{Na}{ }_{2}$ EDTA, 56.6 $\mu \mathrm{M}$ $\mathrm{H}_{3} \mathrm{BO}_{3}, 10.0 \mu \mathrm{M} \mathrm{NaCl}, 5.4 \mu \mathrm{M} \mathrm{FeSO}_{4}, 5.0 \mu \mathrm{M} \mathrm{CoSO}_{4}, 5.0$ $\mu \mathrm{M} \mathrm{Ni}\left(\mathrm{NH}_{4}\right)_{2}\left(\mathrm{SO}_{4}\right)_{2}, 3.87 \mu \mathrm{M} \mathrm{Na} \mathrm{MoO}_{4}, 1.5 \mu \mathrm{M}$ $\mathrm{Na}_{2} \mathrm{SeO}_{4}, 1.26 \mu \mathrm{M} \mathrm{MnSO}, 1.04 \mu \mathrm{M} \mathrm{ZnSO}{ }_{4}, 0.2 \mu \mathrm{M}$ $\mathrm{CuSO}_{4}, \mathrm{~L}$-arginine $\mathrm{HCl}(20 \mathrm{mg} / \mathrm{L})$, L-glutamine $(20 \mathrm{mg} / \mathrm{L})$,
DL-serine (40 mg/L), $0.02 \%$ yeast extract, and $0.01 \%$ bactopeptone. When yeast extract and bactopeptone were excluded from the medium, no growth occurred.

\section{Anaerobic Batch Culture Studies}

Experiments were conducted in a Coy anaerobic chamber under an atmosphere of $10 \%$ hydrogen/balance nitrogen, unless otherwise noted. Inocula were grown overnight aerobically in Luria Broth (LB) liquid medium into late log phase at $30^{\circ} \mathrm{C}$ with shaking. The suspension was centrifuged, washed twice with sterile minimal medium (recipe above), transferred to the anaerobic chamber, and resuspended in medium (prepared anaerobically using a Widdel flask), then dispensed in $0.5-\mathrm{ml}$ aliquots into sterile $250 \mathrm{~mL}$ serum bottles or Wheaton bottles containing $50 \mathrm{~mL}$ of sterile anaerobic medium and capped. Initial absorbance readings at $600 \mathrm{~nm}$ were $\sim 0.05$. Replicates were incubated without agitation at $23-25^{\circ} \mathrm{C}$ in the anaerobic chamber. Lactate was employed as the carbon and energy source and added to $20 \mathrm{mM}$ (unless otherwise noted) from an autoclaved $1 \mathrm{M}$ sodium lactate stock. Formate was added at $20 \mathrm{mM}$ from an autoclaved $1 \mathrm{M}$ sodium formate stock. Chromate was added as electron acceptor in the form of potassium chromate (99.9\%, Sigma, St. Louis, MO) from an anaerobic $500 \mu \mathrm{g} /$ $\mathrm{mL}$ stock solution. Samples were withdrawn in the anaerobic chamber, filtered with a $0.2 \mu$ filter and stored at $-20^{\circ} \mathrm{C}$ until analysis. All stock solutions were stored in serum bottles with a nitrogen headspace and kept in an anaerobic chamber.

In experiments testing for $\mathrm{Cr}(\mathrm{VI})$ reduction during denitrification, nitrate was added to $\sim 2 \mathrm{mM}$ from a $2 \mathrm{M}$ anaerobic stock solution. After 1-2 h, when the nitrate concentration had begun to decrease, cultures were spiked with $\mathrm{Cr}(\mathrm{VI})$ (to a desired concentration ranging from 10-400 $\mu \mathrm{M})$. In experiments testing for growth using $\mathrm{Cr}(\mathrm{VI})$ as sole electron acceptor, 50-75 $\mu \mathrm{M} \mathrm{Cr}(\mathrm{VI})$ was added in sequential spikes to medium without other electron acceptors. In rate experiments, cultures were spiked with $\mathrm{Cr}(\mathrm{VI})$ at 10 $400 \mu \mathrm{M}$. Samples were periodically removed and analyzed for soluble $\mathrm{Cr}(\mathrm{VI})$, nitrate, nitrite, and viable cell count, if applicable. In addition, samples $(2 \mathrm{~mL})$ were centrifuged and the pellets stored at $-20^{\circ} \mathrm{C}$ for subsequent total cellular protein analysis.

\section{Aerobic Batch Culture Studies}

Inocula were grown overnight in LB liquid medium into late $\log$ phase at $30^{\circ} \mathrm{C}$ with shaking. The suspension was centrifuged, washed twice with sterile minimal medium (recipe above), resuspended in medium, then transferred in 1-ml aliquots to $250 \mathrm{~mL}$ Erlenmeyer flasks containing $50 \mathrm{ml}$ of sterile medium. Cultures were incubated at room temperature with shaking $(200 \mathrm{rpm})$ until $\mathrm{OD}_{600}$ readings indicated $\log$ phase growth $(-3.5 \mathrm{~h})$. Potassium chromate was then added to give concentrations ranging from 10-400 $\mu \mathrm{M}$. Subsamples were periodically removed and analyzed for 
soluble $\mathrm{Cr}(\mathrm{VI})$ and $\mathrm{OD}_{600}$. In addition, 2-mL samples were centrifuged and the pellets stored at $-20^{\circ} \mathrm{C}$ for subsequent total cellular protein analysis.

\section{Analytical Methods}

Soluble Cr(VI) was determined colorimetrically using 1,5diphenyl-carbazide in a sulfuric acid solution ( $\mathrm{pH}$ 2) (Sandell, 1959). Samples were filtered with $0.2 \mu \mathrm{m}$ filters prior to analysis. Absorbance was measured at $540 \mathrm{~nm}$ using a Uvikon XL Spectrophotometer (Bio-Tek Instruments). Total soluble $\mathrm{Cr}$ was measured using a TJA IRIS Advantage/ 1000 Radial ICAP Spectrometer with a solid state CID Detector. Nitrate and nitrite were measured using ion chromatography with a LC 20 ion chromatograph (Dionex, Sunnyvale, CA) equipped with CD 25 detector and an IonPac AS11-HC (4 mm) column (Dionex) using a sodium hydroxide buffer $(25 \mathrm{mM} \mathrm{NaOH})$ at a flow rate of 1.5 $\mathrm{ml} / \mathrm{min}$. Lactate and acetate were determined using ion chromatography with a $1 \mathrm{mM} \mathrm{NaOH}$ buffer. Protein was measured using the Bradford assay (Sapan et al., 1999). Viable cell numbers were determined by colony counts on LB medium.

\section{Reaction Kinetics}

Kinetics were described with a saturation kinetics expression:

$$
-d \mathrm{Cr}(\mathrm{VI}) / d \mathrm{t}=\mathrm{q}_{\max }\left[\mathrm{Cr}(\mathrm{VI}) /(\mathrm{K}+\mathrm{Cr}(\mathrm{VI})]^{* \mathrm{X}}\right.
$$

where $d \mathrm{Cr}(\mathrm{VI}) / d \mathrm{t}=\mathrm{Cr}(\mathrm{VI})$ reduction of rate $[\mu$ moles $\mathrm{Cr}(\mathrm{VI})$ reduced/L-h]; $\mathrm{q}_{\max }=$ maximum specific $\mathrm{Cr}(\mathrm{VI})$ reduction rate $[\mu$ moles $\mathrm{Cr}(\mathrm{VI}) \mathrm{reduced} / \mathrm{mg}$ biomass (protein)-h]; $\mathrm{K}=$ half-saturation coefficient [ $\mu$ moles $\mathrm{Cr}(\mathrm{VI}) /$ $\mathrm{L}] ; \mathrm{X}=$ biomass concentration [mg biomass (as protein)/ $\mathrm{L}] ; \mathrm{Cr}(\mathrm{VI})=\mathrm{Cr}(\mathrm{VI})$ concentration $[\mu \mathrm{moles} / \mathrm{L}]$. Kinetic parameters were obtained using a nonlinear least-squares fit of the specific rate data using Micromath's software program The Scientist.

\section{TEM/EELS}

MR-1 cells were grown aerobically overnight on LB liquid medium, pelleted, and washed in growth buffer three times. The washed cells were used to inoculate $180 \mathrm{~mL}$ serum bottles containing $5 \mathrm{mM}$ nitrate and $10 \mathrm{mM}$ lactate in the minimal medium previously described. After $16 \mathrm{~h}\left(\mathrm{OD}_{600}\right.$ $=0.6$ ), sodium chromate was added to a final concentration of $0.2 \mathrm{mM}$. After $24 \mathrm{~h}, \mathrm{Cr}(\mathrm{VI})$ was completely reduced. The cells were centrifuged and the supernatant discarded. A series of pelleting and resuspension steps followed. Bacterial cells were fixed in a mixture consisting of $2 \%$ acrolein, $2 \%$ glutaraldehyde, and $2 \%$ paraformaldehyde in HEPES $(\mathrm{pH}$ 7.5) buffer for $30 \mathrm{~min}$ at room temperature. Cells were washed three times in buffer and three times in doubledistilled water, each for $3 \mathrm{~min}$. The cells were dehydrated by an ethanol series of $70 \%, 90 \%$, and $100 \%$ for 5 min each at $4^{\circ} \mathrm{C}$, followed by three 5 -min changes of absolute ethanol at room temperature. The cells were then infiltrated in a 1:1 mixture of absolute ethanol and Dow Epoxy resin (DER) for $1 \mathrm{~h}$ and left overnight in $100 \%$ resin. The cells were embedded in DER and cured for $24 \mathrm{~h}$ at $60^{\circ} \mathrm{C}$. The blocks were thin-sectioned at 120-150 nm using a Leica Ultracut UCT ultramicrotome. Sections were either left unstained or stained with lead for less than $1 \mathrm{~min}$.

The sections were examined by a JEOL $4000 \times$ transmission electron microscope (TEM) operated at $397 \mathrm{kV}$. EELS spectroscopy is based on the energy loss experienced by a TEM beam electron that ionizes an atom as it is transmitted through a thin section. The energy loss associated with the ionization of inner shell electrons is element-specific. Thus, elemental composition can be derived from analyzing the energy loss of electrons. For $\mathrm{Cr}$, the ionization occurs at $\mathrm{L}_{2}$ and $\mathrm{L}_{3}$ shells, thus producing a spectrum with two peaks. The peaks correspond to an abrupt increase in electron energy loss immediately above the threshold energy of ionization of an inner shell electron. For transition metals, the valence of the element will affect peak position and the ratio of the area under the $\mathrm{L}_{2}$ and $\mathrm{L}_{3}$ peaks (for $\mathrm{Cr}$ ). Thus, peak position and the peak area ratio of an element are used as fingerprints for a valence state based on the spectra of valence standards. Additionally, by selecting electrons with a specific energy loss the distribution of the corresponding element in the specimen can be visualized (Elemental Mapping). Detailed reviews of the EELS technique are available (Gubbens and Krivanek, 1993; Egerton, 1996).

The electron energy loss spectroscopy (EELS) spectra and the energy-filtered images were acquired with a Gatan GIF200 charge couple device (CCD) camera and processed by DigitalMicrograph v. 3.4 software. The spectra and filtered images were corrected for dark current and channelto-channel gain variation of the CCD camera. EELS spectra were obtained in the imaging mode of the TEM and in the spectroscopy mode of the GIF system with an energy dispersion of $0.1 \mathrm{eV} / \mathrm{channel}$. The collection angle was $2 \beta=$ 100 mrad. The chromium elemental maps were collected using the three-window method with pre-edges at 545 and $560 \mathrm{eV}$ and a post-edge at $580 \mathrm{eV}$ with a slit width of $20 \mathrm{eV}$.

EELS spectra were collected for the following standards: sodium chromate, $\mathrm{Cr}(\mathrm{III})$ oxide, and $\mathrm{Cr}(\mathrm{III}) \mathrm{Cl}_{3}$. The standards (in powder form) were placed on a carbon-coated $\mathrm{Cu}$ grid and placed directly in the sample holder. The sample holder was then placed under vacuum. EELS spectra were analyzed to determine the ratio of the area under the $\mathrm{L}_{3}$ and $\mathrm{L}_{2}$ chromium peaks. First, the background subtraction feature of DigitalMicrograph was used to remove the background. The surface area under each peak was determined by integration of a $3 \mathrm{eV}$ region around the top of the peak (a $5 \mathrm{eV}$ region gives the same result) using a modified version of the Flat Two Step method (Daulton et al., 2002) and the ratio of the two peaks was calculated.

TEM images of stained sections were also obtained by a JEOL 2000FX microscope operating at $80 \mathrm{kV}$ and equipped with a Teitz TemCam F224 $2 \mathrm{~K} \times 2 \mathrm{~K}$ CCD camera. 


\section{RESULTS AND DISCUSSION}

\section{Cr(VI) Reduction Without Additional Electron Acceptors Present}

The capacity of MR-1 to reduce $\mathrm{Cr}(\mathrm{VI})$ in the absence of other electron acceptors was investigated. All experiments were performed in the minimal medium defined in the previous section. MR-1 reduced $\mathrm{Cr}(\mathrm{VI})$ with lactate as the electron donor (Fig. 1) but not formate (data not shown). Controls prepared without cells, without lactate, and with autoclaved cells showed little decrease in $\mathrm{Cr}(\mathrm{VI})$ concentration (approximately 20, 36, and $20 \mu \mathrm{M}$, respectively, over 10 days). Abiotic reduction of $\mathrm{Cr}(\mathrm{VI})$ could have resulted from lactate, yeast extract, bactopeptone, or $\mathrm{Fe}(\mathrm{II})$ in the medium. In controls with cells but without lactate, yeast extract and bactopeptone could have initially been used as electron donor. $\mathrm{Cr}(\mathrm{VI})$ reduction in the absence of electron donor has also been described by Fein et al. (2002). As expected for an anion such as $\mathrm{CrO}_{4}{ }^{2-}$, adsorption was not observed at this pH. $\mathrm{Cr}(\mathrm{VI})$ reduction in autoclaved controls did not differ from abiotic controls.

MR-1 cultures were unable to grow during the reduction of $\mathrm{Cr}(\mathrm{VI})$, as indicated by viable cell count (Fig. 1) and total cellular protein (data not shown). Colony-forming units did not increase after the addition of almost $175 \mu \mathrm{M} \mathrm{Cr}(\mathrm{VI})$. In addition, the specific activity of $\mathrm{Cr}(\mathrm{VI})$ reduction decreased with each addition of $\mathrm{Cr}(\mathrm{VI})$. If $\mathrm{Cr}(\mathrm{VI})$ reduction supported growth, the rate of reaction would increase. These results suggest secondary utilization or cometabolism as the mechanism for $\mathrm{Cr}(\mathrm{VI})$ reduction.

\section{Cr(III) Solubilization}

Total soluble chromium was measured at the end of experiments in order to probe for the presence of soluble $\mathrm{Cr}(\mathrm{III})$. At the $\mathrm{pH}$ of most groundwater, $\mathrm{Cr}(\mathrm{III})$ formed from $\mathrm{Cr}(\mathrm{VI})$ reduction will precipitate as insoluble $\mathrm{Cr}(\mathrm{III})$ hydroxides (Jardine et al., 1999). However, $\mathrm{Cr}(\mathrm{III})$ is known to complex with organic ligands (Nieboer and Jusys, 1988). Soluble $\mathrm{Cr}(\mathrm{III})$ is commonly computed as the difference between total soluble $\mathrm{Cr}$ and total soluble $\mathrm{Cr}(\mathrm{VI})$. In medium containing lactate as electron donor, $13-14 \%$ of the reduced $\mathrm{Cr}$ (III) remained soluble, presumably as a complex to lactate or components of yeast extract or bactopeptone. When $100 \mathrm{mM}$ HEPES was included in the medium as a buffer, the percentage of soluble $\mathrm{Cr}(\mathrm{III})$ increased to $47 \%$. This observation is important for bioremediation of $\mathrm{Cr}(\mathrm{VI})$ because the EPA maximum contaminant level (MCL) is measured in terms of total soluble $\mathrm{Cr}$, including both soluble $\mathrm{Cr}(\mathrm{VI})$ and $\mathrm{Cr}(\mathrm{III})$.

\section{Cr(VI) Reduction During Denitrification}

MR-1 can reduce nitrate to nitrite to $\mathrm{N}_{2} \mathrm{O}$ coupled to growth (Krause and Nealson, 1997). Batch studies were performed in minimal medium to study simultaneous $\mathrm{Cr}(\mathrm{VI})$ and nitrate reduction. Cultures were spiked with $5 \mathrm{mM}$ lactate and $\sim 2 \mathrm{mM}$ nitrate and allowed to grow for several hours to ensure the onset of nitrate reduction. $\mathrm{Cr}(\mathrm{VI})$ was then added at $\sim 6$ and $45 \mu \mathrm{M}$ to a subset of the bottles. As shown in Figure 2, in the absence of $\mathrm{Cr}(\mathrm{VI})$ lactate was oxidized to acetate, nitrate was reduced to nitrite, and nitrite was almost completely reduced (presumably to $\mathrm{N}_{2} \mathrm{O}$ ). When $\mathrm{Cr}(\mathrm{VI})$ was added at $6 \mu \mathrm{M}, \mathrm{Cr}(\mathrm{VI})$ was reduced during nitrate and nitrite reduction. Patterns of lactate oxidation, nitrate and nitrite reduction, and growth were nearly identical to controls without $\mathrm{Cr}(\mathrm{VI})$. However, when $\mathrm{Cr}(\mathrm{VI})$ was added at 45 $\mu \mathrm{M}$, nitrate reduction was immediately inhibited and nitrite reduction stopped. $\mathrm{Cr}(\mathrm{VI})$ concentrations were reduced to the MCL $(2 \mu \mathrm{M})$. Controls without lactate showed no nitrate reduction (data not shown). No Cr (VI) reduction was observed in abiotic controls containing nitrate, nitrite, and Cr (VI) (data not shown).

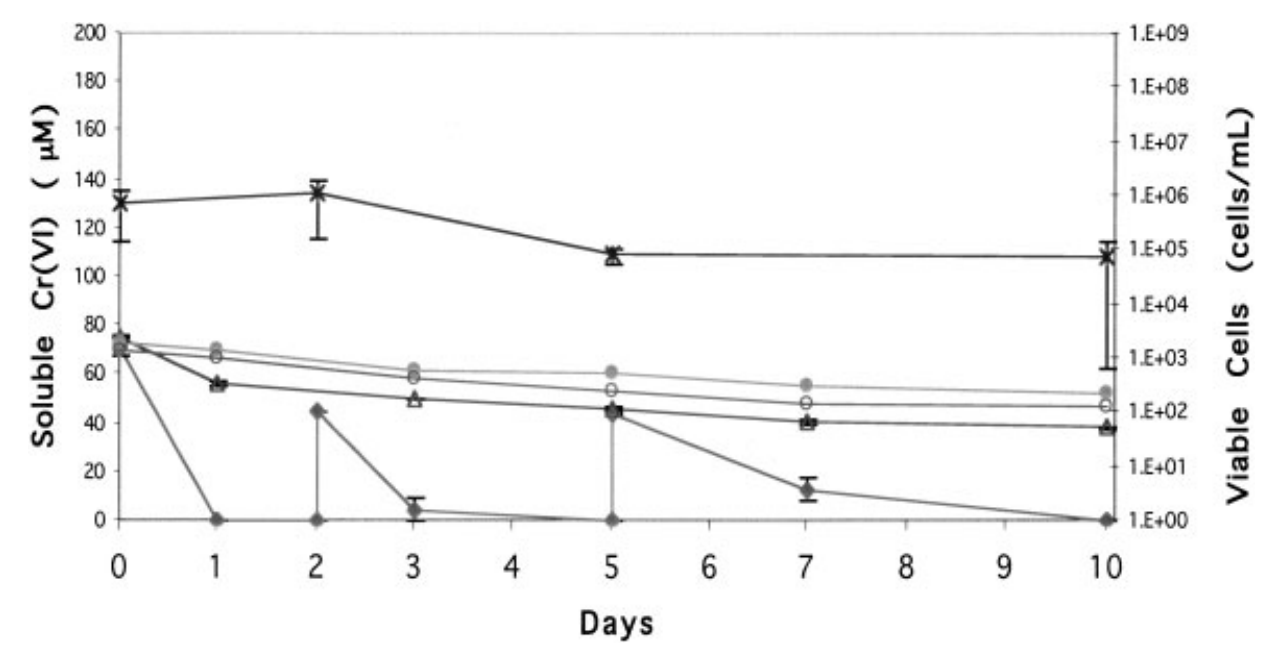

Figure 1. Shewanella oneidensis MR-1 reduces $\mathrm{Cr}(\mathrm{VI})$ in the absence of other electron acceptors, but does not grow on $\mathrm{Cr}(\mathrm{VI})$. Where error bars are shown, values are the average of duplicates and error bars represent the range. $50 \mu \mathrm{M} \mathrm{Cr}(\mathrm{VI})$ was added at day 2 and $5 .(\diamond), \mathrm{MR}-1+$ lactate $+\mathrm{Cr}(\mathrm{VI})$; $(\triangle), \operatorname{MR}-1+\mathrm{Cr}(\mathrm{VI}) ;(\bullet), \mathrm{Cr}(\mathrm{VI})+$ lactate; $(\mathrm{O})$, autoclaved MR-1 + lactate + $\mathrm{Cr}(\mathrm{VI})$; and $(*)$, viable cell count for MR-1 + lactate + Cr(VI). 

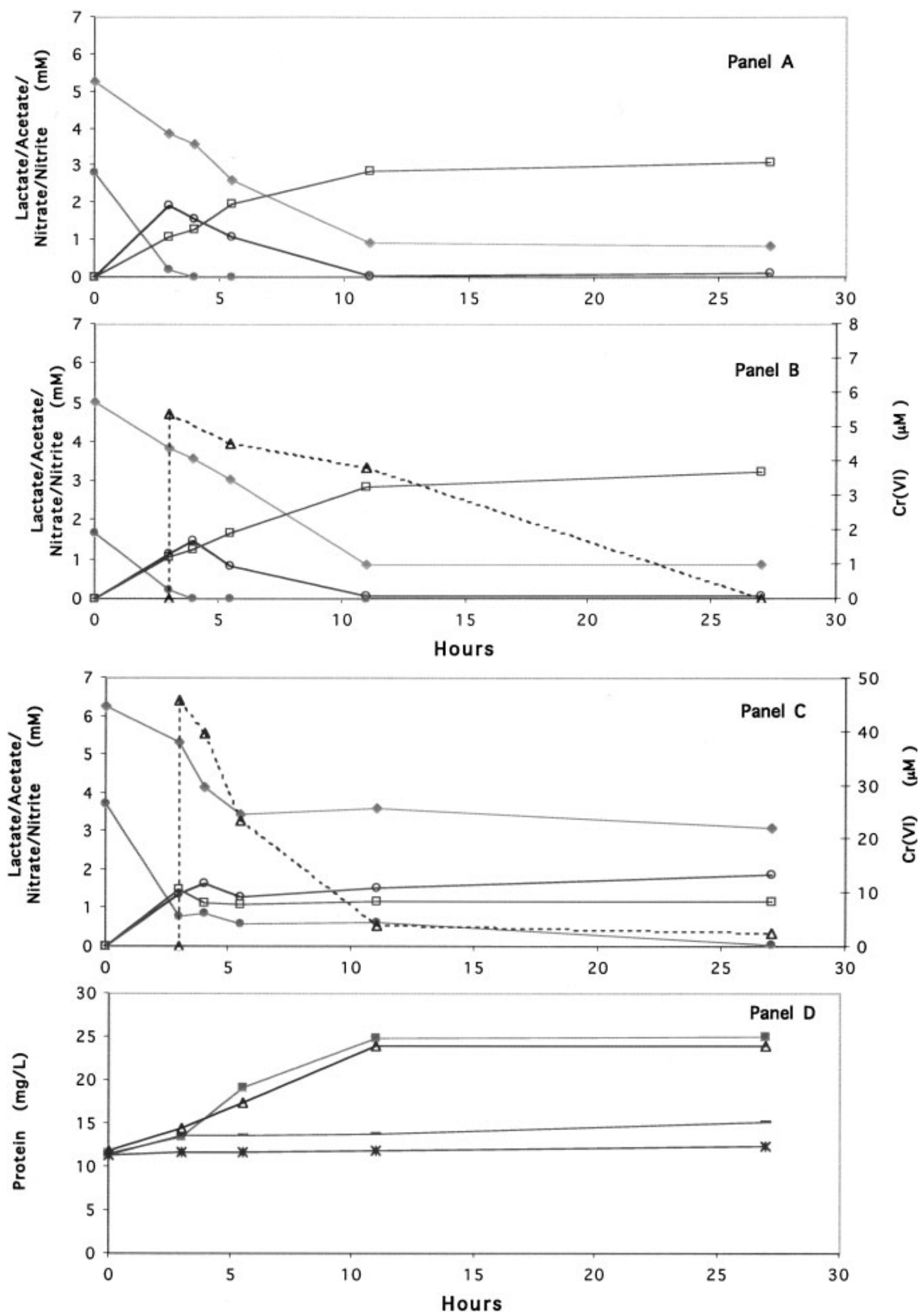

Figure 2. MR-1 reduces nitrate and nitrite and oxidizes lactate to acetate in the absence of $\mathrm{Cr}(\mathrm{VI})(\mathbf{A})$ and with $6 \mu \mathrm{M} \mathrm{Cr}(\mathrm{VI})(\mathbf{B}) .45 \mu \mathrm{M} \mathrm{Cr}(\mathrm{VI})(\mathbf{C})$ severely inhibits the rate of nitrate and nitrite reduction and lactate oxidation. Growth is inhibited by $45 \mu \mathrm{M} \mathrm{Cr}(\mathrm{VI})$ or the absence of lactate (D). Cr(VI)

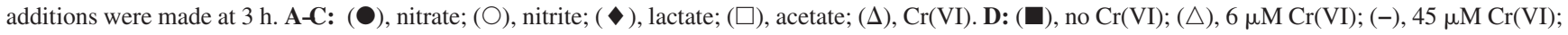
$(*)$, no lactate. 


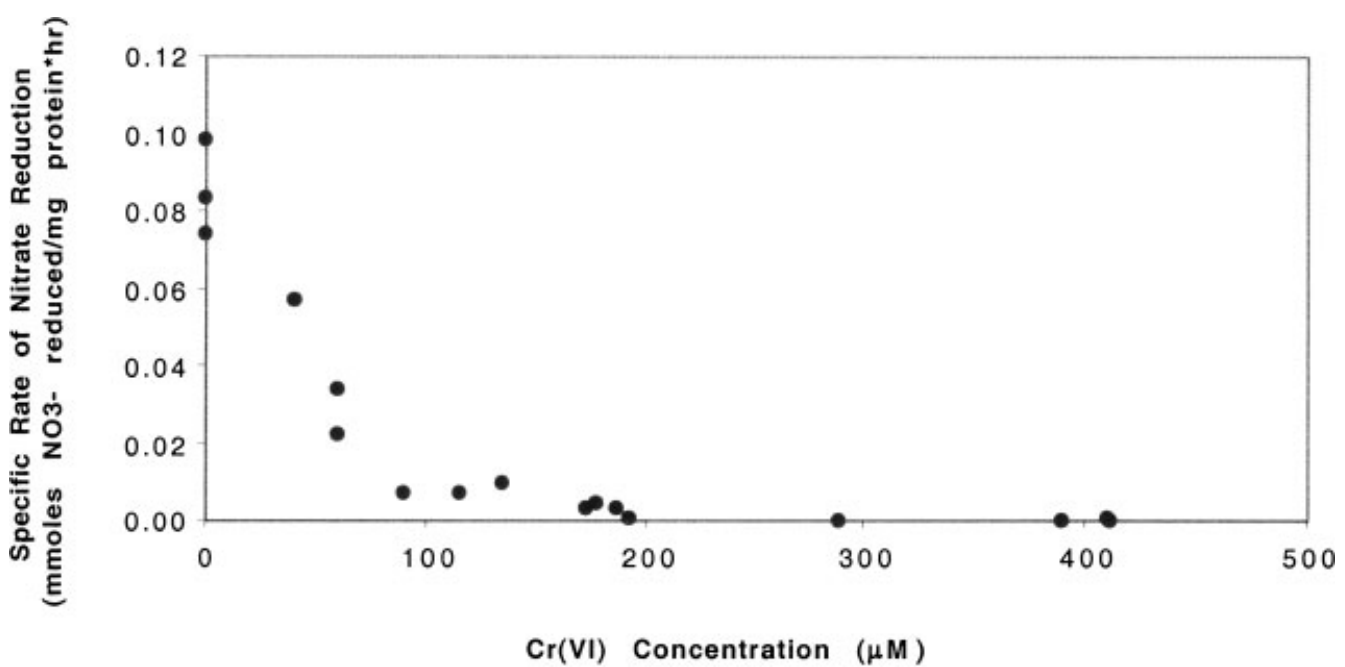

Figure 3. Inhibition of nitrate reduction. As $\mathrm{Cr}(\mathrm{VI})$ concentrations increase, the specific rate of nitrate reduction decreases. The initial nitrate concentration was $2 \mu \mathrm{M}$. Above $190 \mu \mathrm{M}$ Cr(VI), nitrate reduction stops.

Additional experiments elucidated the effect of varying $\mathrm{Cr}(\mathrm{VI})$ concentrations on specific rates of nitrate reduction. Cultures were spiked with $2 \mathrm{mM}$ nitrate and allowed to grow for $\sim 30$ min before being spiked with $\mathrm{Cr}(\mathrm{VI})$. Specific rates of nitrate reduction were computed from data points taken in the first $2 \mathrm{~h}$ following addition of $\mathrm{Cr}(\mathrm{VI})$. Figure 3 displays the specific rate of nitrate reduction as a function of initial $\mathrm{Cr}(\mathrm{VI})$ concentration. Initial rates of nitrate reduction decreased with increasing levels of $\mathrm{Cr}(\mathrm{VI})$. Above $190 \mu \mathrm{M}$ $\mathrm{Cr}(\mathrm{VI})$, nitrate reduction stopped.

An electron balance was determined for nitrate and chromate reduction by MR-1. Using the following half reactions, the changes in lactate, nitrate, and $\mathrm{Cr}(\mathrm{VI})$ concentration could be expressed in terms of moles of electron equivalents:

$$
\begin{gathered}
\mathrm{C}_{3} \mathrm{H}_{5} \mathrm{O}_{3}{ }^{-}+2 \mathrm{H}_{2} \mathrm{O}=\mathrm{C}_{2} \mathrm{H}_{3} \mathrm{O}_{2}^{-}+4 \mathrm{e}^{-}+\mathrm{HCO}_{3}^{-}+5 \mathrm{H}^{+} \\
\mathrm{NO}_{3}{ }^{-}+2 \mathrm{H}^{+}+2 \mathrm{e}^{-}=\mathrm{NO}_{2}{ }^{-}+\mathrm{H}_{2} \mathrm{O} \\
\mathrm{CrO}_{4}{ }^{2-}+4 \mathrm{H}_{2} \mathrm{O}+3 \mathrm{e}^{-}=\mathrm{Cr}(\mathrm{OH})_{3}(\mathrm{~s})+5 \mathrm{OH}^{-}
\end{gathered}
$$

Assuming that the oxidation of lactate to acetate was the dominant oxidation reaction in our system (controls with no lactate showed no nitrate reduction or growth), then the fraction of electrons used for nitrate reduction to nitrite can be compared with the fraction used for $\mathrm{Cr}(\mathrm{VI})$ reduction to $\mathrm{Cr}$ (III). The fraction of electrons transferred to nitrate was computed as the electron equivalents consumed through nitrate reduction (prior to the onset of nitrite reduction) divided by the corresponding total electron equivalents of lactate oxidized. A value of $0.6 \pm 0.1(n=6)$ was obtained in the absence of $\mathrm{Cr}(\mathrm{VI})$; a value of $0.5 \pm 0.1(\mathrm{n}=2$, range given) was obtained in the presence of $\mathrm{Cr}(\mathrm{VI})$. The fraction transferred to $\mathrm{Cr}(\mathrm{VI})$ was computed as the electron equivalents consumed by $\mathrm{Cr}(\mathrm{VI})$ reduction divided by the corresponding electron equivalents of lactate oxidized over the course of $\mathrm{Cr}(\mathrm{VI})$ reduction. A value of $0.001 \pm 0.0001(\mathrm{n}=$
2, range given) was obtained at $7 \mu \mathrm{M} \mathrm{Cr}(\mathrm{VI})$; this value increased to $0.016 \pm 0.00003(\mathrm{n}=3)$ at $40-50 \mu \mathrm{M} \mathrm{Cr}(\mathrm{VI})$. A larger fraction of electrons is transferred to $\mathrm{Cr}(\mathrm{VI})$ at higher initial $\mathrm{Cr}(\mathrm{VI})$ concentrations where $\mathrm{Cr}(\mathrm{VI})$ reduction rates are faster. To ensure that the hydrogen present in the headspace (taken from the anaerobic chamber) did not influence calculations, experiments were repeated using inert gases in the headspace ( $\mathrm{He}$ and $\mathrm{N}_{2} / \mathrm{CO}_{2}$ ). There was no statistical difference in the values.

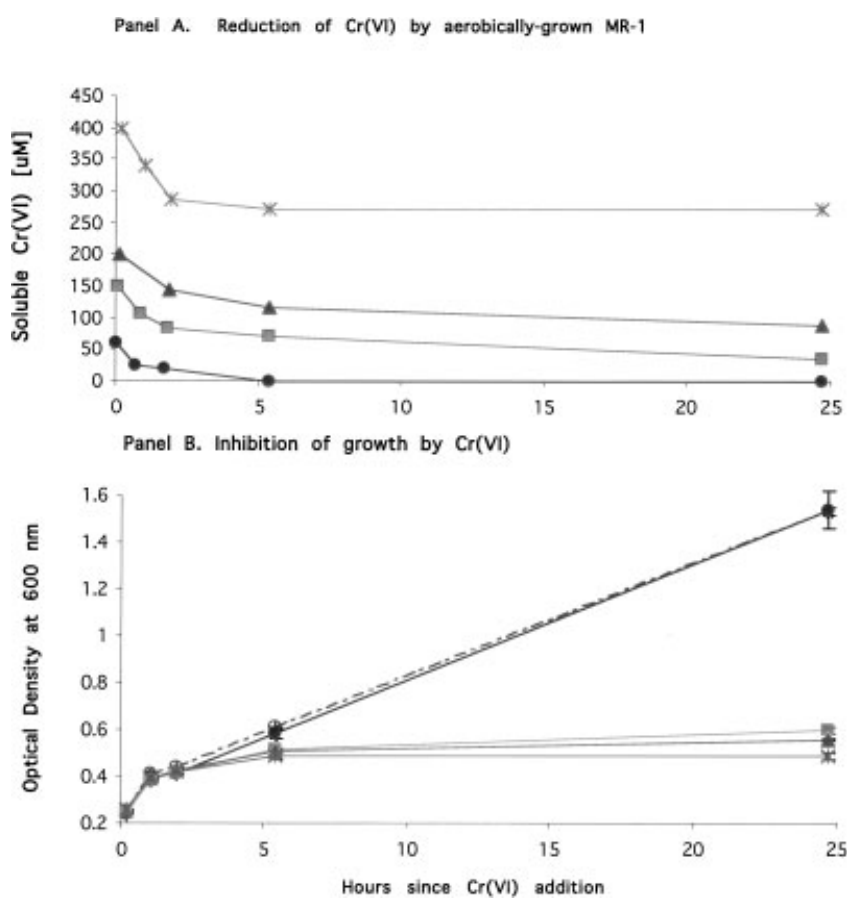

Figure 4. MR-1 reduces $\mathrm{Cr}(\mathrm{VI})$ during aerobic growth on lactate (A). Growth is inhibited in cultures dosed with 150,200 , and $400 \mu \mathrm{M} \mathrm{Cr}(\mathrm{VI})$, but not $60 \mu \mathrm{M}(\mathbf{B})$. Values for OD are the average of duplicates, with error bars representing the range. $(\bullet), 60 \mu \mathrm{M} \mathrm{Cr}(\mathrm{VI}) ;(\mathbf{\square}), 150 \mu \mathrm{M} \mathrm{Cr}(\mathrm{VI}) ;(\mathbf{\Delta})$, $200 \mu \mathrm{M} \mathrm{Cr}(\mathrm{VI}) ;(*), 400 \mu \mathrm{M}$ Cr(VI); (-O-) no $\mathrm{Cr}(\mathrm{VI})$. 
Table I. 48-h $\mathrm{Cr}(\mathrm{VI})$ transformation capacity of $S$. oneidensis MR-1 under three experimental conditions following a single spike of $\mathrm{Cr}(\mathrm{VI})$ ranging from $200-500 \mu \mathrm{M}$.

\begin{tabular}{lc}
\hline \multicolumn{1}{c}{$\begin{array}{c}\text { Experimental } \\
\text { condition }\end{array}$} & $\begin{array}{c}\text { Transformation } \\
\text { capacity } \pm \text { one } \\
\text { standard deviation } \\
\text { [mg Cr(VI) } \\
\text { reduced/mg protein] }\end{array}$ \\
\hline $\begin{array}{l}\text { Resting cells with Cr(VI) as only e- acceptor } \\
\text { In the presence of nitrate }\end{array}$ & $\begin{array}{l}0.78 \pm 0.31(\mathrm{n}=6) \\
\text { Aerobic conditions }\end{array}$ \\
\hline
\end{tabular}

These results demonstrate the simultaneous reduction of $\mathrm{Cr}(\mathrm{VI})$ and nitrate and the inhibitory effect of $\mathrm{Cr}(\mathrm{VI})$ on denitrification. The low fraction of electrons directed to $\mathrm{Cr}(\mathrm{VI})$ suggests secondary utilization or a cometabolic process.

\section{Cr(VI) Reduction During Aerobic Growth}

Studies were performed to study $\mathrm{Cr}(\mathrm{VI})$ reduction during aerobic growth. $\mathrm{Cr}$ (VI) was added in the early logarithmic phase of growth at varying concentrations. Approximately $100 \mu \mathrm{M} \mathrm{Cr}(\mathrm{VI})$ was reduced when lactate was present as electron donor (Fig. 4), irrespective of the amount of $\mathrm{Cr}(\mathrm{VI})$ added. In abiotic controls with lactate and $\mathrm{Cr}(\mathrm{VI}), \sim 23 \mu \mathrm{M}$ was reduced in $20 \mathrm{~h}$ (data not shown). As discussed earlier, this reduction was likely due to abiotic reduction of $\mathrm{Cr}(\mathrm{VI})$ by medium components. Slightly more $\mathrm{Cr}(\mathrm{VI})$ was reduced in controls without electron donor $(27 \mu \mathrm{M})$, as seen previously for anaerobic resting cells. Growth was inhibited in aerobic cultures exposed to 150,200 , and $400 \mu \mathrm{M} \mathrm{Cr}(\mathrm{VI})$; $60 \mu \mathrm{M} \mathrm{Cr}(\mathrm{VI})$ had little effect (Fig. 4b). A lag time of $\sim 2 \mathrm{~h}$ was observed before inhibition of growth occurred.

\section{Transformation Capacity}

When spiked with concentrations of $\mathrm{Cr}(\mathrm{VI})$ above $150 \mu \mathrm{M}$, MR-1 gradually lost its ability to reduce $\mathrm{Cr}(\mathrm{VI})$ with time under both anaerobic and aerobic (Fig. 4) conditions. This may indicate a finite reduction capacity per cell. The concept of transformation capacity (Tc) was first introduced by Alvarez-Cohen and McCarty (1991), who defined it, for resting cells, as the mass of nongrowth substrate transformed per unit of biomass. In this work, Tc was estimated as the mass of $\mathrm{Cr}(\mathrm{VI})$ reduced per unit biomass present $(\mathrm{mg}$ protein) after $48 \mathrm{~h}$. A duration of $48 \mathrm{~h}$ was chosen because the rate of $\mathrm{Cr}(\mathrm{VI})$ reduction typically approached zero by this time. The mass of $\mathrm{Cr}(\mathrm{VI})$ reduced in controls without cells was subtracted from the overall mass transformed. We used data from resting cultures of MR-1 and from those grown on nitrate and oxygen to compute transformation capacities. These values were significantly different for aerobic and anaerobic conditions and are shown in Table I.

The rate of $\mathrm{Cr}(\mathrm{VI})$ reduction decreased gradually for resting cells receiving sequential spikes of 50-75 $\mu \mathrm{M} \mathrm{Cr}(\mathrm{VI})$ (Fig. 1). However, sequential spikes of lower levels of $\mathrm{Cr}(\mathrm{VI})$ allowed for a larger transformation capacity over a longer duration than single spikes of higher $\mathrm{Cr}(\mathrm{VI})$ concentrations. In resting anaerobic cultures, up to $3.5 \mathrm{mg}(67 \mu \mathrm{M})$ $\mathrm{Cr}(\mathrm{VI}) \cdot[\mathrm{mg} \text { protein }]^{-1}$ was reduced with sequential spikes of $\sim 75 \mu \mathrm{M} \mathrm{Cr}(\mathrm{VI})$ over the course of 30 days (data not shown), as opposed to $0.78 \mathrm{mg} \mathrm{Cr}(\mathrm{VI}) \cdot[\mathrm{mg} \text { protein }]^{-1}$ for

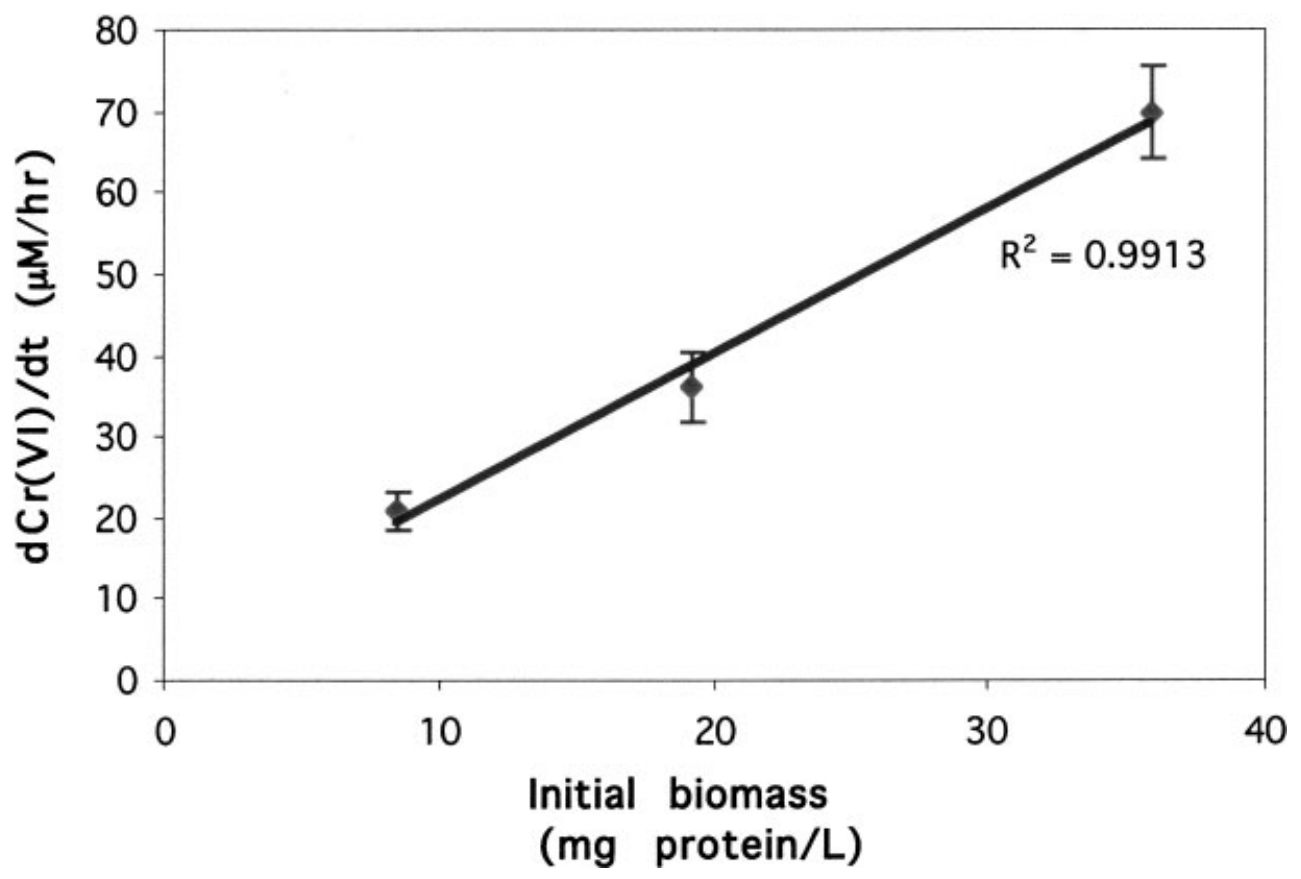

Figure 5. The rate of $\mathrm{Cr}(\mathrm{VI})$ reduction by MR-1 cells is first order with respect to biomass concentration. Cells were resting anaerobically with [Cr(VI)] $=250 \mu \mathrm{M}$ and no other electron acceptors. Values are the average of triplicates $\pm 1 \mathrm{SD},(\diamond), \mathrm{dCr}(\mathrm{VI}) / \mathrm{dt}$. 


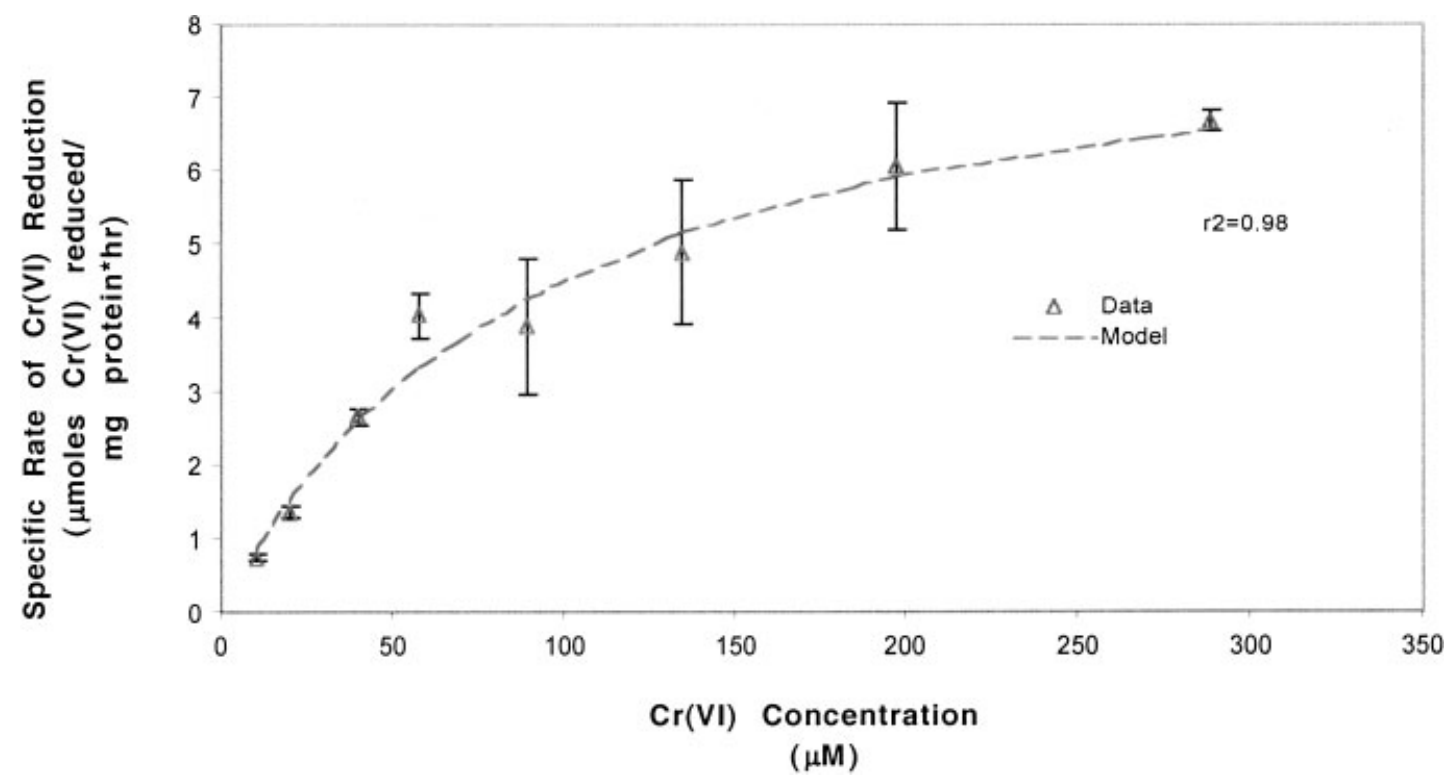

Figure 6. Specific rate of $\mathrm{Cr}(\mathrm{VI})$ reduction as a function of $\mathrm{Cr}(\mathrm{VI})$ concentration for resting cells of MR-1. Data points are the averages of triplicates with error bars representing $\pm 1 \mathrm{SD}$, except for the value at $\mathrm{Cr}(\mathrm{VI})=300 \mu \mathrm{M}$, which is an average of duplicates where the error bars represent the range. Fitting values for $\mathrm{K}$ and $\mathrm{q}_{\max }$ are provided in Table 2. $(\triangle)$, data; (-), model.

cells exposed to a single spike of $\mathrm{Cr}(\mathrm{VI})$ at higher concentrations. This suggests that transformation capacity is limited by $\mathrm{Cr}(\mathrm{VI})$ toxicity at higher concentrations. The limited transformation capacity per unit biomass compounded by the inhibitory effect of $\mathrm{Cr}(\mathrm{VI})$ on growth could pose a challenge for chromate bioremediation.

\section{Reaction Kinetics}

Studies were performed to evaluate reaction kinetics. The $\mathrm{Cr}(\mathrm{VI})$ reduction rate was first order with respect to biomass (Fig. 5). Rate experiments were carried out under the three electron-acceptor conditions studied. $\mathrm{Cr}(\mathrm{VI})$ was added at $10-400 \mu \mathrm{M}$ to batch cultures of MR-1. Data points taken in the first $0-2 \mathrm{~h}$ following $\mathrm{Cr}(\mathrm{VI})$ addition were used to compute initial rates of $\mathrm{Cr}(\mathrm{VI})$ reduction, which were then normalized to the biomass present during the same time period. As shown in Figure 6, the kinetic data followed a saturation kinetics pattern, with specific rates approaching a maximum, $\mathrm{q}_{\max }$, at higher concentrations. Table II provides a summary of the kinetic parameters for all three electronacceptor conditions; $\mathrm{q}_{\max }$ under anaerobic conditions was an order of magnitude larger than under aerobic conditions. However, $\mathrm{q}_{\max }$ for anaerobic cells with and without nitrate were not statistically different, in contrast to results reported by Viamajala et al. (2002). The contrasting results may be explained by differences in experimental conditions such as growth phase of cells and time elapsed during rate measurements, as well as the fact that our parameters were obtained through the modeling of data taken at a wide range of $\mathrm{Cr}(\mathrm{VI})$ concentrations.

For all three electron accepting conditions, the values for $\mathrm{K}(29-88 \mu \mathrm{M})$ are much larger than the regulatory standard of $1.9 \mu \mathrm{M}$. This indicates that first-order kinetics would likely limit the rates of $\mathrm{Cr}(\mathrm{VI})$ reduction and rates will decrease as concentrations fall. Since initial rates of $\mathrm{Cr}(\mathrm{VI})$ reduction are used in the computation of $\mathrm{q}_{\max }$ and $\mathrm{K}$, we did not consider the effects of transformation capacity.

\section{TEM/EELS}

TEM images of cells in the presence of chromium showed electron-dense precipitates both around and inside cells (Fig. 7A). The majority of cells contained intracellular pre-

Table II. Kinetic parameters for S. oneidensis MR-1 under three electron-accepting conditions.

\begin{tabular}{|c|c|c|c|}
\hline Experimental condition & $\begin{array}{l}\mathrm{q}_{\max } \text { maximum specific } \mathrm{Cr}(\mathrm{VI}) \\
\text { reduction rate }[\mu \text { moles } \mathrm{Cr}(\mathrm{VI}) \\
\text { reduced/mg biomass (protein)-h] }\end{array}$ & $\begin{array}{c}\mathrm{K} \text { half-saturation coefficient } \\
{[\mu \text { moles } \mathrm{Cr}(\mathrm{VI}) / \mathrm{L}]}\end{array}$ & $r^{2}$ \\
\hline Resting cells with $\mathrm{Cr}(\mathrm{VI})$ as only e- acceptor & $8 \pm 2$ & $74 \pm 24$ & $0.95 \pm 0.04$ \\
\hline In the presence of nitrate & $6 \pm 2$ & $88 \pm 15$ & $0.94 \pm 0.03$ \\
\hline Aerobic conditions & $0.6 \pm 0.1$ & $29 \pm 6$ & $0.9 \pm 0.02$ \\
\hline
\end{tabular}

Values are based on a nonlinear least squares fit of the specific rate data using saturation kinetics (see text). Experiments were performed in triplicate and standard deviations are indicated. 


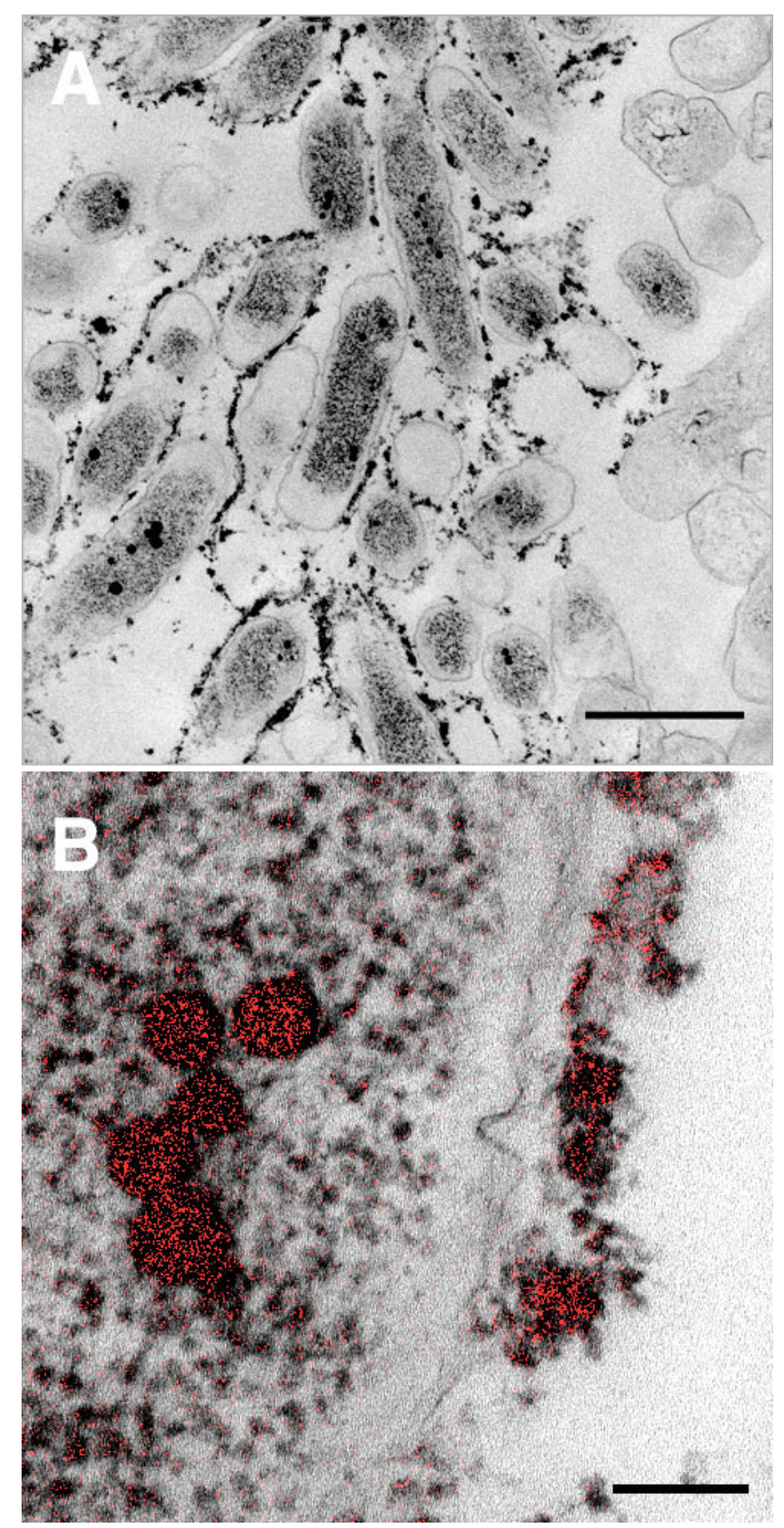

Figure 7. A: Transmission electron microscopy (TEM) image of $S$. oneidensis MR-1 after reduction of $0.2 \mathrm{mM} \mathrm{Cr}(\mathrm{VI})$. Cells were grown on nitrate. Sections with stained with lead. Bar $=1 \mu \mathrm{m}$. B: Electron energy loss spectroscopy (EELS) was used to create an elemental map of chromium (red) overlaid on a zero energy loss filtered image of an MR-1 cell (section stained with lead). The electron-dense precipitates both inside and outside the cell are reduced chromium, including the electron-dense globules in the cytoplasm. Bar $=25 \mathrm{~nm}$.

cipitates in the form of round globules. Electron-dense precipitates were not observed in cells that were not exposed to chromium (not shown). An elemental map of chromium overlaid on a zero-energy-loss filtered image of an MR-1 cell (stained with lead) showed that the electron-dense precipitates outside the cell and the large electron-dense globules inside the cells were chromium (Fig. 7B). To our knowledge, this is the first report of round globules of re- duced chromium within cells. In addition, there was a significant amount of intracellular chromium that was not associated with the globules but diffused throughout the cytoplasm. A study of the peak position and the peak ratio relative to the oxidation state showed that chromium associated with cells (both intracellularly and extracellularly) does not correspond to $\mathrm{Cr}$ (VI) (Fig. 8). It appears to be most closely related to $\mathrm{Cr}$ (III) but does not overlap either of the two Cr(III) forms probed (chloride and oxide). The structure and position of the $\mathrm{L}_{2}$ and $\mathrm{L}_{3}$ chromium peaks depend on the local electronic structure of the atom. Both the oxidation state and the chemical environment of the chromium atoms determine the position and the ratio of the two peaks. Therefore, it is likely that the chromium in and around the cells is in a reduced form (most likely $\mathrm{Cr}$ (III)) but the definitive chemical form is unknown. These results strongly suggest that $\mathrm{Cr}(\mathrm{VI})$ is transformed inside cells.

A recent EELS study examined $\mathrm{Cr}(\mathrm{VI})$ reduction by MR-1 (Daulton et al., 2002). They showed chromium in a reduced oxidation state (probably $\mathrm{Cr}(\mathrm{III})$ ) surrounding the cells, but did not identify intracellular chromium. Their conditions differed from this study in that the cells were exposed to $0.1 \mathrm{mM} \mathrm{Cr}(\mathrm{VI})$ as the sole terminal electron acceptor for 30 days. In our 2-day experiments, $\mathrm{Cr}(\mathrm{VI})$ was added at $0.2 \mathrm{mM}$ to cells grown on nitrate as the terminal electron acceptor. The absence of intracellular chromium in their work is not necessarily incompatible with our results. Their study did not include an elemental map of the cell thin section. It is conceivable that there was chromium present intracellularly but did not form the distinctive round globules that we found in our system due to differences in experimental conditions. Other researchers have observed similar round bodies of reduced selenium in the cytoplasm of Ralstonia metallidurans CH34 (Roux et al., 2001).

There are widespread reports of the intracellular interaction of Cr(III) with DNA (Gulanowski et al., 1992; Zhitkovich et al., 1996). $\mathrm{Cr}$ (III) has been reported to crosslink the phosphate backbone of DNA with peptides and amino acids such as cysteine and histidine (Zhitkovich et al., 1996). We postulate that the round globules present in a large number of the cells is due to this cross-linking, causing $\mathrm{Cr}$ (III) to be bound to phosphate and amino groups. This might explain the imperfect match with the exclusively inorganic standards used to characterize the peak position and $\mathrm{L}_{3} / \mathrm{L}_{2}$ peak area ratio. $\mathrm{Cr}$ (III) interaction with DNA is known to increase the rate of DNA polymerase bypass of DNA lesions resulting in an increase in spontaneous mutagenesis (Snow, 1994). The observed inhibitory effect of $\mathrm{Cr}(\mathrm{VI})$ on the growth and metabolism of MR-1 may be due to the deleterious interaction of intracellular $\mathrm{Cr}$ (III) with DNA.

\section{CONCLUSIONS}

Many electron acceptors are present in contaminated systems and often vary spatially and with time. That MR- 1 is able to reduce $\mathrm{Cr}(\mathrm{VI})$ in environments containing oxygen or nitrate augers well for its use in bioaugmentation applica- 


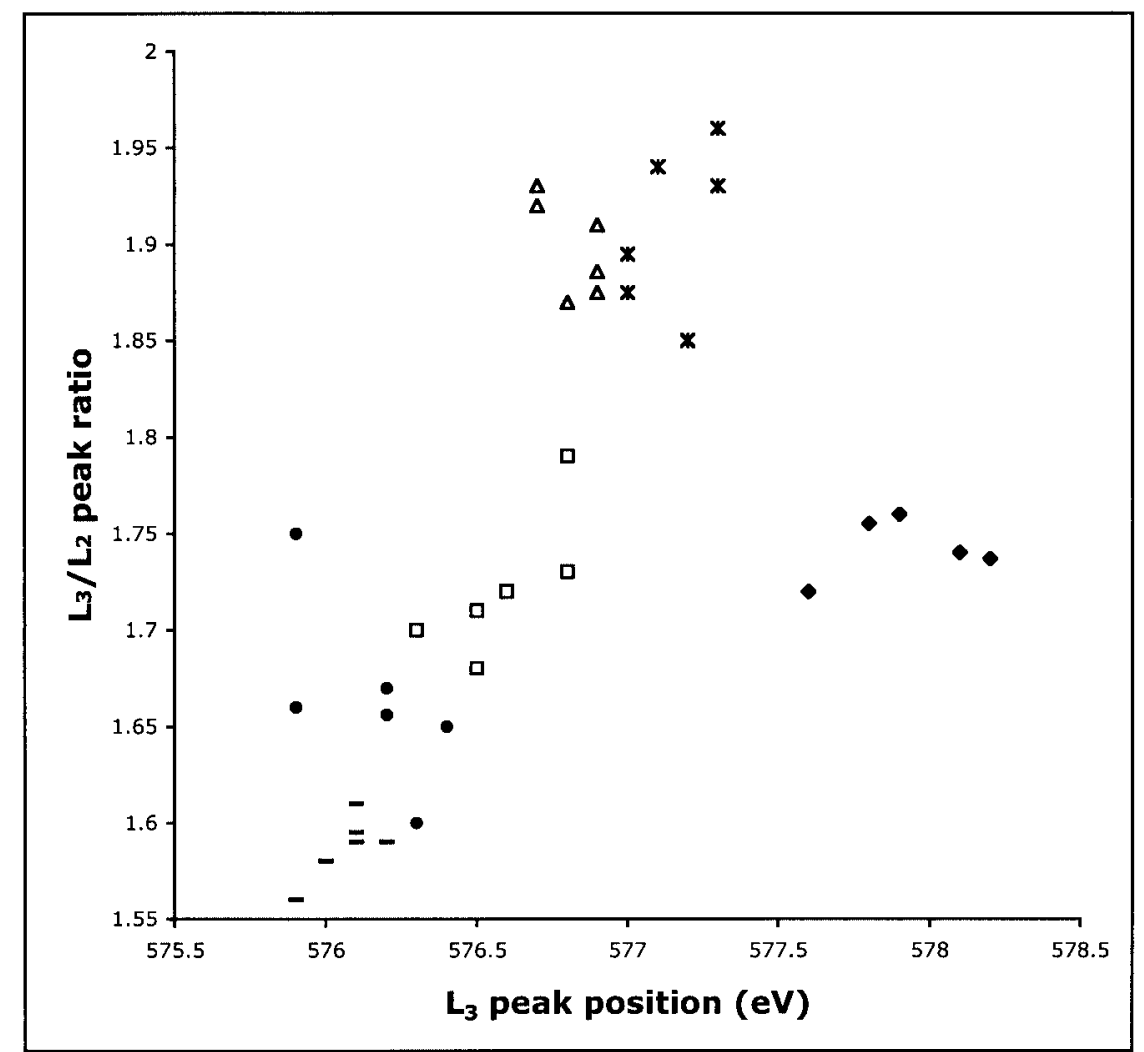

Figure 8. A study of the peak position and the peak ratio relative to the oxidation state indicate that the chromium associated with cells (both intracellularly and extracellularly) does not correspond to $\mathrm{Cr}(\mathrm{VI})$. Results suggest the chromium is in a reduced state. (-), $\mathrm{Cr}$ inside the cells; $(\bullet), \mathrm{Cr}$ outside the cells; $(\diamond), \mathrm{Cr}(\mathrm{VI})$ standard; $(\triangle), \mathrm{Cr}(\mathrm{III})$ oxide standard; $(\square), \mathrm{Cr}(\mathrm{III}) \mathrm{Cl}_{3}$ standard.

tions. Bacteria often preferentially utilize more energetically favorable electron acceptors. For example, in the presence of nitrate, reduction of $\mathrm{Mn}(\mathrm{IV})$, thiosulfate, and $\mathrm{Fe}(\mathrm{III})$ in Shewanella putrefaciens 200 was inhibited, indicating that nitrate was the preferred electron acceptor for anaerobic respiration (DiChristina, 1992). Although oxygen and nitrate have half-reaction reduction potentials that are higher or comparable (respectively) to $\mathrm{Cr}(\mathrm{VI}), \mathrm{MR}-1$ is able to reduce $\mathrm{Cr}(\mathrm{VI})$ while reducing both of these electron acceptors. These results suggest that in bioremediation applications, the ability of MR-1 to reduce $\mathrm{Cr}(\mathrm{VI})$ would not be inhibited by oxygen or nitrate. However, it is clear that kinetic parameters vary significantly between oxic and anoxic conditions.

Our results also indicate that $\mathrm{Cr}(\mathrm{VI})$ inhibits aerobic growth and denitrification above certain levels. This may influence the sequence in which electron acceptors are reduced in a mixed waste setting. For example, the presence of toxic levels of $\mathrm{Cr}(\mathrm{VI})$ may hinder denitrification and prevent the redox potential of the system from decreasing to levels where other electron acceptors are reduced. Toxicity also appears to limit $\mathrm{Cr}(\mathrm{VI})$ transformation capacity; sequential spikes of lower levels of $\mathrm{Cr}(\mathrm{VI})$ allowed for a larger transformation capacity over a longer duration than single spikes of a higher $\mathrm{Cr}(\mathrm{VI})$ concentration. Although the mechanism of $\mathrm{Cr}(\mathrm{VI})$ toxicity in MR-1 is not well understood, TEM and EELS studies revealed reduced chromium precipitates both within and surrounding cells, including intracellular reduced chromium globules, that may contribute to the inhibitory effects of chromium.

We thank James Bouwer from the National Center for Microscopy and Imaging Research for help with the Gatan Imaging Filter. We also thank Jizhong Zhou for supplying the MR-1 strain used in this study, and Alfred Spormann and Weimin Wu for helpful suggestions on the manuscript.

\section{References}

Alvarez-Cohen L, McCarty PL. 1991. A cometabolic biotransformation model for halogenated aliphatic compounds exhibiting product toxicity. Environ Sci Technol 25:1381-1387.

Bopp LH, Ehrlich HL. 1988. Chromate resistance and reduction in Pseudomonas fluorescens strain LB300. Arch Microbiol 150:426-431.

Daulton TL, Little BJ, Lowe K, Jones-Meeham J. 2002. Electron energy loss spectroscopy techniques for the study of microbial chromium(VI) reduction. J Microbiol Methods 50:39-54.

DiChristina TJ. 1992. The effects of nitrate and nitrite on dissimilatory iron reduction in Shewanella putrefaciens 200. J Bacteriol 174:1891-1896.

Eary L, Rai D. 1987. Kinetics of chromium(III) oxidation to chromium(VI) by reaction with manganese dioxide. Environ Sci Technol 21: 1187-1193.

Egerton RF. 1996. Electron energy-loss spectroscopy in the electron microscope. New York: Plenum Press.

Fein JB, Fowle DA, Cahill J, et al. 2002. Nonmetabolic reduction of Cr(VI) by bacterial surfaces under nutrient-absent conditions. Geomicrobiol J 19:369-382. 
Francis CA, Obraztsova AY, Tebo BM. 2000. Dissimilatory metal reduction by the facultative anaerobe Pantoea agglomerans SP1. Appl Environ Microbiol 66:543-548.

Gubbens AJ, Krivanek OL. 1993. Applications of a post-column imaging filter in biology and materials science. Ultramicroscopy 51:146-159.

Gulanowski B, Swiatek J, Kozlowski H. 1992. Impact of chromium ions on nucleoside triphosphates and nucleic acids. J Inorg Biochem 48: 289-298.

Ishibashi Y, Cervantes C, Silver S. 1990. Chromium reduction in Pseudomonas putida. Appl Environ Microbiol 56:2268-2270.

Jardine PM, Fendorf SE, Mayes MA, et al. 1999. Fate and transport of hexavalent chromium in undisturbed heterogeneous soil. Environ Sci Technol 33:2939-2944.

Kostka JE, Nealson KH. 1995. Dissolution and reduction of magnetite by S. putrefaciens. Environ Sci Technol 29:2535-2540.

Krause B, Nealson KH. 1997. Physiology and enzymology involved in denitrification by Shewanella putrefaciens. Appl Environ Microbiol 63:2613-2618.

Lloyd JR, Macaskie LE. 1996. A novel phosphorimager-based technique for monitoring the microbial reduction of technetium. Appl Environ Microbiol 62:578-582.

Lovley DR, Phillips EJP, Lonergan DJ. 1989. Hydrogen and formate oxidation coupled to dissimilatory reduction of iron or manganese by Alteromonas putrefaciens. Appl Environ Microbiol 55:700-706.

Lovley DR, Phillips EJP, Gorby YA, et al. 1991. Microbial reduction of uranium. Nature 350:413-415.

Moser DP, Nealson KH. 1996. Growth of the facultative anaerobe Shewanella putrefaciens by elemental sulfur reduction. Appl Environ Microbiol 62:2100-2105.

Myers CR, Nealson KH. 1988. Bacterial manganese reduction and growth with manganese oxide as the sole electron acceptor. Science 240: 1319-1321.

Myers CR, Nealson KH. 1990. Respiration-linked proton translocation coupled to anaerobic reduction of manganese (IV) and iron (III) in Shewanella putrefaciens MR-1. J Bacteriol 172:6232-6238.

Myers CR, Carstens BP, Antholine WE, et al. 2000. Chromium (VI) re- ductase activity is associated with the cytoplasmic membrane of anaerobically grown Shewanella putrefaciens MR-1. J Appl Microbiol 88:98-106.

Nieboer E, Jusys AA. 1988. Biologic chemistry of chromium. In: Nriagu JO, Nieboer E, editors. Chromium in the natural and human environments. New York: John Wiley \& Sons. p 31-33.

Rege MA, Petersen JN, Johnstone DL, et al. 1997. Bacterial reduction of hexavalent chromium by Enterobacter cloacae strain $\mathrm{HO} 1$ grown on sucrose. Biotechnol Lett 19:691-694.

Roux M, Sarret G, Pignot-Paintrand I, et al. 2001. Mobilization of Selenite by Ralstonia metallidurans CH34. Appl Environ Microbiol 67: 769-773.

Sandell EB. 1959. Colorimetric determination of traces of metals. New York: Interscience Publishers.

Sapan CV, Lundblad RL, Price NC. 1999. Colorimetric protein assay techniques. Biotechnol Appl Biochem 29:99-108.

Shen H, Wang Y. 1993. Characterization of enzymatic reduction of hexavalent chromium by Escherichia coli ATCC 33456. Appl Environ Microbiol 59:3771-3777.

Snow ET. 1994. Effects of chromium on DNA replication in vitro. Environ Health Perspect 102(Suppl 3):41-44.

Tebo BM, Obraztsova AY. 1998. Sulfate-reducing bacterium grows with $\mathrm{Cr}(\mathrm{VI}), \mathrm{U}(\mathrm{VI}), \mathrm{Mn}(\mathrm{IV})$, and Fe(III) as electron acceptors. FEMS Microbiol Lett 162:193-198.

Viamajala S, Peyton BM, Apel WA, et al. 2002a. Chromate reduction in Shewanella oneidensis MR-1 is an inducible process associated with anaerobic growth. Biotechnol Prog 18:290-295.

Viamajala S, Peyton BM, Apel WA, et al. 2002b. Chromate/nitrite interactions in Shewanella oneidensis MR-1: evidence for multiple hexavalent chromium $[\mathrm{Cr}(\mathrm{VI})]$ reduction mechanisms dependent on physiological growth conditions. Biotechnol Bioeng 78:770-777.

Zhitkovich A, Voitkun V, Costa M. 1996. Formation of the amino acidDNA complexes by hexavalent and trivalent chromium in vitro: importance of trivalent chromium and the phosphate group. Biochemistry 35:7275-7282. 